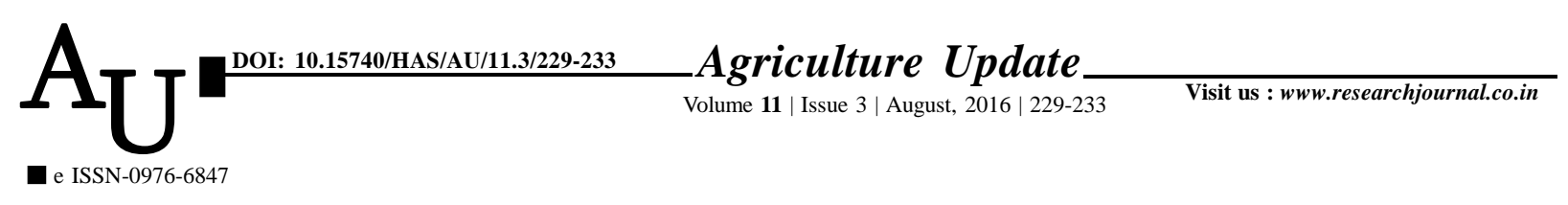

\title{
Research Article: Constraints faced by farmers in drip irrigation system
}

\section{S.D. PARMAR AND G.N. THORAT}

Article Chronicle: SUMMARY : The study was conducted to identify the constraints in adopting the drip irrigation Received : 08.06.2016;

Revised : 20.06.2016; Accepted :

01.07.2016 system by collecting data from 150 farmers in Anand and Vadodara Districs of Gujarat. The data analyzed by statically tools. The constraints were grouped into four categories viz., economic, technological, administrative and personal socio-psychological constraints. The major constraints faced by farmers in adopting drip irrigation system were time-to-time attention for minor repairs (3.88), inadequate and uncertainly in power supply (3.86), frequent clogging of drippers and microtubes (3.78), heavy initial expenses (3.56) and lack of technical know-how as well as lack of proper training.

How to cite this article : Parmar, S.D. and Thorat, G.N. (2016). Constraints faced by farmers in drip irrigation system. Agric. Update, 11(3): 229-233, DOI : 10.15740/HAS/AU/11.3/229-233.

KEY WoRds:

Constraints, Adoption, Drip irrigation system (DIS)

Author for correspondence :

\section{G.N. THORAT}

Pashu Vigyan Kendra, Tribal Research cum Training Centre (AAU), Devgadh Bariya, DAHOD (GUJARAT) INDIA

Email: gunvantthorat@ rediffmail.com

See end of the article for authors' affiliations 